\title{
PENGARUH LARUTAN BAWANG PUTIH (Allium sativum) PADA LARVA Aedes spp DI KECAMATAN MALALAYANG KOTA MANADO
}

\author{
${ }^{1}$ Simone P M Sumampouw \\ ${ }^{2}$ Victor D Pijoh \\ ${ }^{2}$ Greta J P Wahongan \\ ${ }^{1}$ Kandidat Skripsi Fakultas Kedokteran Universitas Sam Ratulangi Manado \\ ${ }^{2}$ Bagian Ilmu Kedokteran Parasitologi Klinik, Fakultas Kedokteran \\ Universitas Sam Ratulangi Manado \\ Email: simone.merielle@yahoo.co.uk
}

\begin{abstract}
Aedes spp known as vectors in the transmission of dengue fever. It is a major target in the effort to reduce the numbers of dengue patients. The number of problems that can be caused by insecticides was the basic thinking about what safer way to eradicate mosquito larvae in this form. Garlic health sector has been widely studied example of the anti-microbial effect against $H$. pylori and antiparasitic against Cappilaria spp. The content of the compounds found in garlic and its derivatives which are Allicin. Allicin also be larvicides. Method: This research method was a experimental laboratory. The purpose of this study was to determine the effect of garlic solution to the larvae of Aedes spp in District Malalayang Manado City. 240 eggs Aedes spp was used as a sample in this study, taken by simple random sampling method. Concentration used in this study were $0 \%, 1 \%, 5 \%$, $10 \%, 15 \%$ and $20 \%$. This study was conducted with four replications. The independent variable in this study was the concentration of a solution of garlic and dependent variable was the larvae of Aedes spp. Results: The results showed that garlic solution effect on larvae of Aedes spp. There is a significant difference (ANOVA, $\mathrm{p}<0.05$ ) between the number of dead larvae untreated group with the treated group. There is a proportional relationship between the increase in the concentration of garlic solution with the number of dead larvae of Aedes spp.
\end{abstract}

Keywords: Aedes spp, Garlic Solution, Allium sativum.

\begin{abstract}
Abstrak: Aedes spp adalah nyamuk yang sekarang dikenal sebagai vektor dalam menularkan demam berdarah dengue. Karena itu nyamuk ini menjadi target utama dalam usaha menurunkan angka penderita DBD. Banyaknya masalah yang dapat ditimbulkan oleh insektisida menjadi dasar pemikiran tentang cara apa yang lebih aman untuk membasmi nyamuk dalam hal ini bentuk larva. Dibidang kesehatan bawang putih sudah banyak diteliti mengenai efek anti mikroba misalnya terhadap H.pylori dan antiparasit terhadap Cappilaria spp. Kandungan senyawa yang ditemukan pada bawang putih diantaranya adalah Allicin. Allicin dan turunannya juga bersifat larvasida. Metode: Metode penelitian ini bersifat eksperimental laboratorium. Tujuan penelitian ini yaitu untuk mengetahui pengaruh larutan bawang putih terhadap larva Aedes spp di Kecamatan Malalayang Kota manado. Sampel penelitian yaitu 240 telur yang kemudian dipelihara sampai menjadi larva yang diambil berdasarkan metode simple random sampling. Kosentrasi yang dipakai pada penelitian ini yaitu 0\%, 1\%, 5\%, 10\%, 15\% dan 20\%.Penelitian ini dilakukan dengan empat kali pengulangan.Variabel bebas pada penelitian ini adalah konsentrasi larutan bawang putih dan variabel tergantung adalah larva Aedes spp. Hasil: Hasil menunjukkan bahwa larutan bawang putih berpengaruh terhadap larva Aedes spp. Terdapat perbedaan signifikan (Anova, $\mathrm{p}<0,05$ ) jumlah larva yang mati antara kelompok yang tidak diberi perlakuan dengan kelompok yang diberi perlakuan. Terdapat hubungan berbanding lurus antara peningkatan konsentrasi larutan bawang putih dengan jumlah larva Aedes spp yang mati.
\end{abstract}

Kata kunci: Aedes spp, Larutan Bawang Putih, Allium sativum. 
Nyamuk termasuk dalam kelas Insekta, ordo Diptera dan family Culicidae. Nyamuk dapat mengganggu manusia dan binatang melalui gigitannya serta berperan sebagai vektor penyakit pada manusia dan binatang yang penyebabnya terdiri atas berbagai macam parasit. ${ }^{1}$ Aedes spp adalah nyamuk yang sekarang dikenal sebagai vektor dalam menularkan demam berdarah dengue. Karena itu nyamuk ini menjadi target utama dalam usaha menurunkan angka penderita DBD. $^{2}$ Nyamuk Aedes spp bertelur dan berkembang biak pada air yang bersih. Seperti pada tempat penampungan air unutk keperluan sehari-hari: bak mandi, WC, tempayan, drum air, sumur gali. Wadah yang berisi air bersih atau air hujan: tempat minum burung, vas bunga, pot bunga, ban bekas, kaleng botol dan sebagainya. ${ }^{3}$

Demam berdarah dengue (DBD) merupakan masalah kesehatan masyarakat di Indonesia karena jumlah penderitanya terus bertambah dan penyebarannya semakin luas. Penyakit ini ditularkan melalui gigitan nyamuk penular (vektor) yaitu nyamuk Aedes spp. Insidensi penyakit ini menunjukkan peningkatan yang dramatis di seluruh dunia baik frekuensi kasus maupun epidemi penyakitnya. ${ }^{4}$

Di propinsi Sulawesi Utara, penyakit DBD pertama kali ditemukan di Manado pada tahun 1973 kemudian berturut-turut menyebar ke berbagai daerah di Sulawesi Utara. Angka insiden DBD di Sulawesi Utara masih sangat tinggi dalam beberapa tahun terakhir ini perkembangan sangat fluktuatif. $^{5}$

Cara utama yang dapat dilakukan untuk memberantas penyakit Demam Berdarag Dengue adalah dengan upaya pengendalian nyamuk penular, karena hingga saat ini belum ditemukan vaksin dan obat membasmi virusnya. Pemberantasan nyamuk dapat dilakukan dengan menyemprotkan insektisida, namun jika hanya dengan menyemprotkan insektisida akan timbul nyamuk baru lagi karena jentik masih dibiarkan hidup. ${ }^{6}$

Pengendalian kimiawi adalah salah satu cara yang sangat relative untuk mengendalikan nyamuk dalam waktu yang singkat, oleh karna itu pengendalian kimiawi adalah pengendalian yang paling banyak digunakan saat ini. Untuk populasi serangga yang sangat tinggi pengendalian ini sangat dianjurkan. Tetapi dalam pemakaian pengendalian ini harus dilakukan secara hati-hati karena pengendalian ini memiliki efek samping yang cukup besar. ${ }^{7}$

Telah banyak masalah yang dapat ditimbulkan oleh insektisida menjadi dasar pemikiran tentang cara apa yang lebih aman untuk membasmi nyamuk dalam hal ini bentuk larva. Tanaman tradisional seperti bawang putih dapat menjadi alternatif pengganti insektisida. Bawang putih dipilih sebagai alternatif oleh karena tanaman ini sudah dikenal oleh masyarakat dan mudah diperoleh di seluruh Indonesia. ${ }^{6}$

Bawang putih telah banyak diteliti dibidang kesehatan mengenai efek mikroba yaitu misalnya terhadap H.pylori dan antiparasit terhadap Cappilaria spp. Di dalam bawang putih terdapat kandungan senyawa yang diantaranya adalah Allicin. Allicin dan turunannya juga bersifat larvasida. ${ }^{7}$

Melihat data diatas maka peneliti ingin melakukan penelitian mengenai pengaruh larutanbawang putih terhadap populasi larva nyamuk Aedes spp di Kecamatan Malalayang Kota Manado.

\section{METODE PENELITIAN}

Metode penelitian ini bersifat eksperimental laboratorium. Penelitian ini dilaksanakan dengan rancangan studi analitik bivariat. Pengambilan sampel dilakukan di Kecamatan Malalayang, Kota Manado. Penelitian dilakukan di Laboratorium Parasitologi Fakultas Kedokteran Universitas Sam Ratulangi Manado. Penelitian ini dilaksanakan dari bulan Oktober 2013-Januari 2014. Pengambilan sampel menggunakan metode simple random sampling, dimana sampel diambil di tempat perindukan yang berpotensi tinggi di kecamatan Malalayang. Jumlah sampel 240 larva. Data yang diperoleh, dikelompokkan dan dimasukkan dalam tabel dan diuji kemaknaannya dengan menggunakan Anova (Analysis os varians). 
Variabel yang ingin diprediksi adalah variabel tegantung yaitu jumlah larva mati sedangkan yang diukur adalah variabel bebas yaitu larutan bawang putih. Sedangkan untuk mencari kekuatan hubungan kedua variabel, dilakukan perhitungan korelasi Pearson.

\section{HASIL DAN PEMBAHASAN}

Penelitian ini dilakukan untuk mengetahui apakah larutan bawang putih memiliki pengaruh terhadap larva Aedes spp.

Pada kelompok kontrol larva coba hanya diberi aquades. Hal ini dilakukan untuk menyingkirkan kemugkinan larva mati disebabkan oleh aquades. Pada hasil didapatkan tidak terdapat larva coba yang mati sehingga aquades dianggap tidak memiliki sifat larvasida terhadap Aedes spp.

Pada penelitian mengenai pengaruh larutan bawang putih terhadap larva Aedes spp ini pemilihan umur larva merupakan hal penting karena larva tersebut menjadi objek dalam penelitian ini. Jika salah memilih umur akan dapat mengakibatkan tingkat kematian larva yang terlalu cepat sehingga akan didapatkan hasil angka yang kurang mewakili. Pada penelitian ini dipilih umur larva 4 hari karena pada umur tersebut ketahanan tubuh larva masih kuat dan sudah produktif. Pemberian makanan untuk larva selama pertumbuhan dan perkembangan harus diperhatikan karena merupakan salah satu yang mempengaruhi pertumbuhan dan perkembangan larva. Pemeliharaan larva diberi makan cairan gula.

Selama penelitian, dilakukan pengukuran suhu dengan menggunakan termometer dan kelembaban dengan menggunakan hygrometer pada ruang penelitian.

Berdasarkan Tabel 1, dapat diketahui bahwa rata-rata suhu ruangan selama peneltian adalah $28^{\circ} \mathrm{C}$, sedangkan kelembaban ruangan selama penelitian adalah $78 \%$. Pada penelitian ini, rata-rata suhu ruangan adalah $28^{\circ} \mathrm{C}$, hal ini sesuai dengan kriteria WHO bahwa rata-rata suhu optimum yang baik bagi spesies larva agar hidup normal adalah $26-28^{\circ} \mathrm{C}$.
Tabel 1. Hasil pengukuran suhu dan kelembaban ruang penelitian

\begin{tabular}{c|c|c}
\hline Tanggal & Suhu $^{\mathbf{0}} \mathbf{C}$ & $\begin{array}{c}\text { Kelembaban } \\
\mathbf{\%}\end{array}$ \\
\hline 27 Desember 2013 & 28 & 78 \\
28 Desember 2013 & 28 & 78 \\
29 Desember 2013 & 28 & 78 \\
5 Januari 2014 & 28 & 78 \\
Rata-rata & 28 & 78 \\
\hline
\end{tabular}

Siklus gonotropik larva akan berhenti total pada suhu dibawah $10^{\circ} \mathrm{C}$ atau diatas $40^{\circ} \mathrm{C}$, karena ditemukan larva yang mati pada suhu-suhu tersebut. Angka-angka ini tergantung dari jenis spesiesnya dan umumya pada kenaikan temperatur sekitas 2-6 ${ }^{\circ} \mathrm{C}$ diatas ambang batas, larva tidak akan bertahan hidup atau mati. Lamanya siklus gonotropik, termasuk proses metabolismenya tergantung dari temperatur. Larva dapat bertahan hidup pada suhu rendah $\left(10^{\circ} \mathrm{C}\right)$, tetapi proses metabolismenya menurun atau bahkan berhenti bila suhu sampai dibawah suhu kritis $\left(4,5^{\circ} \mathrm{C}\right)$. Pada suhu yang lebih tinggi dari $35^{\circ} \mathrm{C}$ mengalami keterbatasan proses fisiologis. Rata-rata suhu optimum untuk pertumbuhan larva adalah $26^{\circ}-28^{\circ} \mathrm{C}$.

Selain suhu, faktor lain yang penting adalah kelembaban. Kelembaban adalah banyaknya uap air yang terkandung dalam udara yang biasanya dinyatakan dalam \%. Pada kelembaban kurang dari 60\%, umur larva akan menjadi pendek karena tidak cukup untuk siklus pertumbuhan parasit dalam tubuh.Rata-rata kelembaban ruang penelitian adalah 78\%. Hal ini sesuai kriteria bahwa kelembaban yang baik untuk kehidupan larva adalah $70-90 \%$ dan ini menghindarkan kematian larva karena kelembaban yang tidak sesuai. ${ }^{8}$

Pada hasil dapat dilihat konsentrasi larutan bawang putih terkecil yang menimbulkan efek larvasida yaitu 1\% dengan rata-rata jumlah larva yang mati sebanyak 20\%. Pada konsentrasi 5\% dengan rata-rata jumlah larva yang mati sebanyak $47 \%, 10 \%$ dengan rata-rata jumlah larva yang mati $82,15 \%$ dengan rata-rata jumlah larva yang mati $97 \%$ dan 20\% menyebabkan jumlah larva mati sebanyak $100 \%$. 
Perhitungan larva yang mati dilakukan 24 jam setelah perlakuan, maka didapatkan hasil seperti pada tabel di bawah ini.

Tabel 2. Hasil perhitungan kematian larva

\begin{tabular}{c|c|c}
\hline $\begin{array}{c}\text { Konsentrasi } \\
\text { (\%) }\end{array}$ & $\begin{array}{c}\text { Jumlah } \\
\text { Larva } \\
\text { Percobaan }\end{array}$ & $\begin{array}{c}\text { Rata-rata } \\
\text { Kematian } \\
\text { Larva (\%) }\end{array}$ \\
\hline Kontrol & 10 & 0 \\
1 & 10 & 20 \\
5 & 10 & 47 \\
10 & 10 & 82 \\
15 & 10 & 97 \\
20 & 10 & 100 \\
\hline
\end{tabular}

Berdasarkan tabel tersebut, konsentrasi yang terendah adalah 1\% dapat membunuh larva Aedes spp sebanyak rata-rata 20\% dalam waktu 24 jam setelah perlakuan. Sedangkan konsentrasi yang tertinggi adalah 20\% dalam 24 jam setelah perlakuan dapat membunuh rata-rata $100 \%$.

Adapun rata-rata kematian larva Aedes spp perlakuan disajikan pada Gambar 1.

Gambar 1 menunjukkan kenaikan tingkat konsentrasi diikuti pula dengan kenaikkan rata-rata kematian larva. Hal ini menunjukkan hubungan yang linier yang berarti semakin besar konsentrasi larutan bawang putih maka semakin tinggi pula kematian larva Aedes spp.

Pada Tabel juga dapat dilihat bahwa pada kelompok kontrol tidak didapatkan adanya larva yang mati. Hal ini berbeda

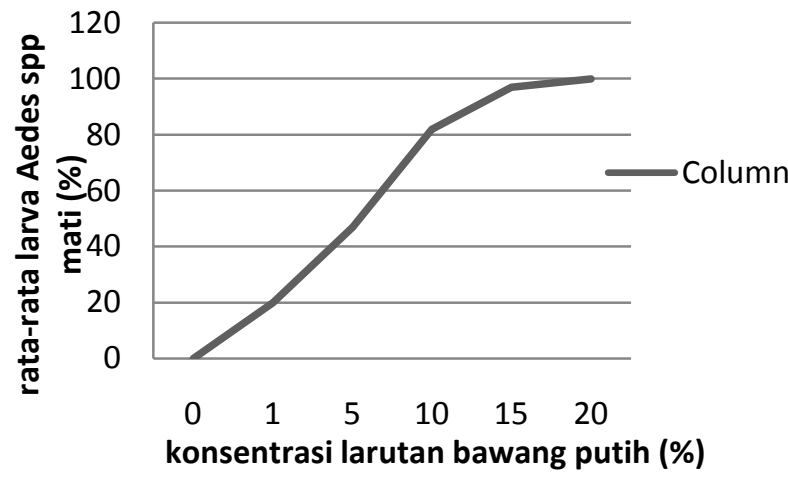

Gambar 1. Grafik rata-rata kematian larva sesuai dengan konsentrasi dengan kelompok perlakuan yang didapatkan adanya larva yang mati.

Untuk membuktikan hipotesa bahwa memang ada perbedaan signifikan antara kelompok kontrol dengan kelompok perlakuan maka digunakan uji hipotesa Anova. Hasilnya didapatkan nilai p sebesar 0,000 dengan $\alpha(0,05)$. Nilai $p$ yang kurang dari $\alpha$ membuat $\mathrm{H}_{\mathrm{o}}$ ditolak dan $\mathrm{H}_{1}$ diterima.Itu berarti ada perbedaan signifikan antara kelompok kontrol dengan kelompok perlakuan.

Penentuan hubungan antara tiap konsentrasi dengan uji korelasi. Uji korelasi memberikan hasil bahwa angka probabilitas adalah 0,000 kurang dai 0,05 maka dua variabel secara nyata berkorelasi, sehingga dengan demikian ada hubungan yang kuat yaitu semakin meningkat konsentrasi maka kematian larva semakin meningkat pula.

Pada tabel didapatkan hasil yang bervariasi dimana jumlah larva mati pada setiap konsentrasi tidak terlalu sama antara kelompok. Hal ini mungkin disebabkan oleh adanya perbedaan sensifitas masing-masing larva coba. Variabel pengganggu yang tidak diteliti seperti kondisi masing-masing larva yang berbeda sebelum dimasukkan ke dalam penelitian mungkin juga dapat mempengaruhi sensifitas larva terhadap perlakuan pemberian larutan bawang putih. Variabel pengganggu lainnya dapat juga berupa trauma yang dialami larva pada saat pengambilan sehingga dapat memudahkan kematian larva walaupun hanya dengan konsentrasi kecil. Adanya trauma pada larva dapat dilihat dengan mengamati gerak larva. Jika larva sudah tidak dapat bergerak aktif maka larva tersebut harus diganti dengan larva yang lain yang masih dapat bergerah secara aktif.

Bawang putih segar mengandung aliin (S-allil-L- sistein sulfoksida) senyawa yang tidak berbau dan tidak memiliki aktifitas biologi. Jika jaringan bawang putih rusak dengan adanya enzin allinase mengubah alliin menjadi allicin, senyawa yang diduga bertanggung jawab atas aktivitas farmakologi bawang putih. Oksidasi allicin dengan adanya udara mengubah allicin menjadi 1,7-ditiaokta-4,5-diena sebagai 
dialil-disulfida yang merupakan konstituen utama dari minyak bawang putih. ${ }^{9}$

Mekanisme larvasida dari bawang putih diduga diperankan oleh zat aktif yang terkandung didalamnya. Allicin bekerja dengan cara mengganggu sintesis membran sel parasit sehingga parasit tidak dapat berkembang lebih lanjut. Allicin juga bersifat toksik terhadap sel parasit maupun bakteri. Allicin bekerja dengan merusak Aulfhidril (SH) yang terdapat pada protein. Diduga struktur membran sel larva terdiri dari protein dengan Sulfhidril. Allicin akan merusak membran sel larva sehingga terjadi lisis. Toksisitas Allicin tidak berpengaruh pada sel mamalia karena sel mamalia memiliki Gluthathione yang dapat melindungi sel mamalia dari efek Allicin. ${ }^{7}$ Berdasarkan mekanisme tersebut maka Allicin dapat menghambat perkembangan larva instar 3 menjadi larva instar 4 atau larva instar 4 tidak akan berubah menjadi pupa dan akhirnya akan mati karena membrane selnya telah rusak.

Garlic oil bekerja dengan mengubah tegangan permukaan air sehingga larva mengalami kesulitan untuk mengambil udara dari permukaan air. Hal ini diduga menyebabkan larva tidak mendapat cukup oksigen untuk pertumbuhannya sehingga menyebabkan kematian larva. ${ }^{7}$

Kandungan dari bawang putih lain yang diduga berperan dalam kematian larva adalah Flavonoid. Zat ini bekerja sebagai inhibitor pernapasan. Flavonoid diduga menggaggu metabolism energi di dalam mitokondria dengan menghambat sistem pengangkutan electron.Adanya hambatan pada sistem pengangkutan elektron akan menghalangi produksi ATP dan menyebabkan penurunan pemakaian oksigen oleh mitokondria. $^{7}$

Dengan demikian penelitian ini telah dapat membukikan bahwa pemberian larutan bawang putih (Allium sativum) memberikan pengaruh signifikan antara kelompok perlakuan dan kelompok kontrol. Dan terdapat korelasi yang kuat antara konsentarsi larutan bawang putih dengan jumlah larva Aedes spp yang mati dengan hubungan yang berbanding lurus yang berarti jika konsentrasi bawang putih ditingkatkan maka jumlah larva Aedes sppyang mati juga akan meningkat

\section{SIMPULAN}

1. Larutan bawang putih (Allium sativum) berpengaruh terhadap larva Aedes spp di Kecamatan Malalayang Kota Manado.

2. Terdapat perbedaan signifikan (Anova, $\mathrm{p}<0,05)$ jumlah larva yang mati antara kelompok yang tidak diberi larutan bawang putih dengan kelompok yang diberi larutan bawang putih.

3. Terdapat hubungan berbanding lurus antara peningkatan konsentrasi larutan bawang putih dengan jumlah larva Aedes spp yang mati.

4. Konsentrasi 10\%, 15\%, 20\% dapat membunuh larva secara efektif karena jumlah larva yang mati lebih dari 50\%.

\section{SARAN}

1. Pada penelitian selanjutnya hendaknya menggunakan larva coba dengan jumlah yang lebih banyak supaya data yang didapat lebih representative.

2. Perlu dilakukan penelitian lebih lanjut mengenai lama dari pengaruh larutan bawang putih terhadap larva Aedes spp.

3. Perlu dilakukan penelitian lebih lanjut mengenai kriteria efektif konsentrasi larutan bawang putih.

4. Perlu dilakukan penelitian lebih lanjut mengenai cara pengelolahan bawang putih yang lebih aplikatif sehingga hasilnya dapat disosialisasikan kepada masyarakat.

5. Perlu dilakukan penelitian lebih lanjut untuk mengetahui secara pasti mengenai kandungan dalam bawang putih yang bekerja sebagai larvasida Aedes spp.

\section{DAFTAR PUSTAKA}

1. Laksmono Widagdo, Besar Tirto Husdodo, Bhinuri. Makara Kesehatan. Juni 2008;12(1):13-19.

2. Hasan W. Mengenal nyamuk Aedes aegypti vektor demam berdarah dengue. 2006 [cited 2013 september 24]. Availabe from 
:http:www.scribd.commobiledocuments383 83861downloadcommit=Download+Now\&s ecret_password=.

3. Departemen Kesehatan Republik Indonesia. 2004. Perilaku dan siklus hidup nyamuk aedes aegypti sangat penting diketahui dalam melakukan kegiatan pemberantasan sarang nyamuk, termasuk pemantauan jentik berkala. [cited 2013 september 24] available from: http://www.depkes.go.id/downloads/ Bulletin\%20Harian\%2010032004.pdf

4. Sutanto I, Ismid SI, dkk. Parasitologi Kedokteran (Edisi Keempat). Jakarta: FKUI; 2008.

5. Ulliadi barrung limbong, SKM. Survey kepadatan jentik aedes aegypti di Kabupaten Minahasa Utara. [cited 2013 september 24].Available from: URL :http://btklmanado.or.id/index/php/berita/51-surveykepadatan-jentik-aedes-aegypti-dikabupaten-minahasa-utara
6. Sulistyoningsih D, Santosa B, Sumanto D. jurnal kesehatan. Efektifitas larutan bawang putih dalam membunuh larva aedes aegypti 2009; 2(2):38-44. http://Jurnal.unimus.ac.id (accessed 38 septemner 2013).

7. Agnetha AY. Efek ekstrak bawang putih (allium sativum $L$ ) sebagai larvasida nyamuk aedes sp. Jurnal Kesehatan.

8. Hasnawiyah Q, Muhamat, Aditya R. Preferensi Nyamuk Aedes sp. Dan Culex sp. Menggunakan Media Cair Limbah Rumah Tangga Di Banjarbaru. Bioscientiae 2012.9(2):40-47.

9. Aras U. Uji Banding Efektivitas Perasan Umbi Bawang Putih (Allium sativum Linn.) 25\% Dengan Ketokonazol 2\% Secara In Vitro Terhadap Pertumbuhan Candida albicans Pada Kandida Vaginalis. Semarang; 2006. 